\title{
Reminiscences of a mathematical sojourn at San Marcos, 1959 - 61, and at IMPA, 1962
}

Reminiscências de uma estadia matemática em San Marcos, 1959 61, e no IMPA, 1962

Jorge Sotomayor*

\begin{abstract}
This evocative essay recounts aspects of the initiation of the author into Mathematics at the University of San Marcos, Lima, Peru, 1959-61, and at the National Institute of Pure and Applied Mathematics, IMPA, Rio de Janeiro, Brazil, 1962. It links four previous mathematical essays: My Geometry Notebook [18]: DOI: 10.13140/RG.2.2.18090.47043, Mathematical Encounters [21], On a list of Ordinary Differential Equations Problems, [22]: http://arxiv.org/abs/1808.10571, and On Mauricio M. Peixoto and the arrival of Structural Stability to Rio de Janeiro, 1955. [23] : https://doi.org/10.1590/0001-3765202020191219
\end{abstract}

Keywords: Peixoto, Tola, San Marcos, IMPA, mathematical initiation.

Resumo: O presente ensaio evocativo relata aspectos pertinentes à iniciação do autor no campo da Matemática, ocorrida na Universidade de San Marcos, Lima, Peru, 1959-61, e no Instituto Nacional de Matemática Pura e Aplicada, IMPA, Rio de Janeiro, Brazil, 1962. Ele enlaça quatro ensaios matemáticos anteriores: My Geometry Notebook [18]: DOI: 10.13140/RG.2.2.18090.47043, Mathematical Encounters [21], On a list of Ordinary Differential Equations Problems, [22]: http://arxiv.org/abs/1808.10571, and On Mauricio M. Peixoto and the arrival of Structural Stability to Rio de Janeiro, 1955. [23] : https://doi.org/10.1590/0001-3765202020191219

Palavras-chave: Peixoto, Tola, San Marcos, IMPA, iniciação matemática.

\footnotetext{
*Instituto de Matemática e Estatística, Universidade de São Paulo, sotp@ime.usp.br
} 


\section{San Marcos: The Sciences Courtyard}

The Schools of Law, Letters, Sciences, and Education were located in the colonial building called "La Casona", now converted into a Museum and Cultural Center, which occupies an entire block in front of the University Park, in the hectic downtown of Lima.

The Institute of Physics and Mathematical Sciences, as a dependency of the Faculty of Sciences, occupied a small sector lateral to an internal charming courtyard (called Sciences Courtyard), surrounded by high pillars on which rested centenary portals. Here and there, standing out among the lawn grass, one could see a lonely cypress, a palm tree ... a rosebush. A fountain whispered at the center ${ }^{1}$.

It was in such a monastic appearance scenario that, between 1959 and 1961, I acquired my basic university mathematics education.

The first year courses were numerous. However, only three or four of them were really demanding and stimulating, coming to be configured in real challenges for my ability and determination.

It was a huge group that had been admitted that year. I knew afterward, that the Institute had adopted the fisherman's strategy: throw a wide net, pick up as much as possible and select later. We were fifty-four little fishes that would be sieved in the first year. There were boys and girls representing all regions and ethnic groups of the country, as well as all social strata, excluding the affluent aristocracy.

That year, I had the opportunity to meet the teachers José Ampuero (1922 $1998)$ and Gerardo Ramos (1928 - 2010). From them, I managed to get the mathematical message implicit in their speeches. The other teachers gave fundamentally operational courses, which also involved a lot of work. The total load seemed huge to me. And it was so.

Even today, I profitably consult Dickson's book "New First Course in the Theory of Equations" [9] which, supplemented with Combinatorial Analysis, constituted the first three quarters of the course of Ramos. Dickson's is an arduous book, but conveys admirable conciseness and objectivity. The last quarter of the course was about Vector Algebra.

\footnotetext{
${ }^{1}$ Photos of La Casona with its charming courtyards can be found here: https://es.wikipedia.org/wiki/Casona_de_la_Universidad_Nacional_Mayor_de_San_Marcos
} 
"Here we are in the stone age in relation to the First World. In France, students who attend the University master all that and more; we have to do something against this condition," answered Ramos, when a sector of the group of students, fatigued and already organized in a union, claimed to slow the pace of the courses.

Ramos was the only teacher who, at the end of his course, had an interview with each student to whom, in possession of a folder with annotations and partial examinations results of each one, he meticulously analyzed his performance. In face of my final numerical grade, which would correspond to a resounding B, he told me: "Your performance has been growing gradually throughout the course. You should continue in this way."

The course of Prof. Ampuero consisted of a detailed exposition of the foundations of Mathematical Analysis, a la Peano. It had the objective of presenting a mathematical subject with all rigor of the Axiomatic Method. Its formal resemblance with Euclidean Geometry fascinated me from the beginning. See the evocative essay [18]. It was the first of the courses in the Mathematical Analysis series, entitled Theoretical Arithmetic and Algebra [2].

With an authority and persuasion, that convinced me immediately, Ampuero said, in a sentencing tone: "The only way to penetrate present day Mathematics is to go through a solid foundation of the number systems."

In parallel, there were courses in Calculus, Synthetic Geometry and Spherical Trigonometry, General Physics, Analytic Geometry, these courses differed in intensity and volume, but not in essence, from those of the Secondary School.

To face the challenge of the initiation into University level Mathematics, I became a full-time student. Without perceiving it, I was alienating myself from the other activities that attracted me during my High School years: chess and soccer, among others.

I adopted the habit of studying at night, sometimes stimulated by drinking coffee. Such wonderful liquid had the magic virtue of numbing for three or four hours the implacable Morpheus, on the eves of exams.

As I began to manage with relative success the avalanche of midterm tests and to glimpse something similar to an understanding, I also started to believe that I had had found a mission: to study Mathematics, and that my harmony with the 
world was processed through that arduous initiation.

The year 1959 was for me of great intellectual intensity. Between March and December, I assimilated a huge volume of new knowledge and fascinating Mathematics and I also acquired a rigid working discipline.

In the second year, the proportion of courses carrying stimulus or messages that I could discern diminished. The course that seemed most interesting to me was the continuation of the Analysis series: Foundations of the Differential and Integral Calculus in one variable. The course of Calculus II: Differentiation and Integration in several variables and Differential Equations (solution methods) also had a very good level of contents and challenge.

It was in 1961, when I was in my third year, that I met Dr. José Tola. Undoubtedly, he was the most important man for Peruvian Mathematics in his time. Tola was the only one in San Marcos with important international mathematical contacts.

Bright polemicist, visionary and developmentalist, he stimulated and supported the scientific vocations of countless compatriots ${ }^{2}$.

Until he was in his eighties, he maintained an active militancy at The Catholic University of Peru.

In the first semester I studied Modern Algebra with him; during the second, I continued with Complex Variables. That year I also studied, with Ramos, Differential Geometry. With Ampuero, I finished the series of Mathematical Analysis.

That year came back the challenges and the encouragement to overcome difficulties in learning mathematics. Still today I consult with satisfaction and assimilate something new in the books of this phase: van der Waerden [24], Alfhors [1], Willmore [25] and Apostol [4].

I had also the privilege to attend the course of The Philosophy of Mathematics, taught by Prof. Francisco Miró Quesada Cantuarias (1918 - 2019), philosopher, with solid mathematical knowledge, politician, writer, and man of culture. His captivating lectures circulated in mimeographed notes [11]. In

\footnotetext{
${ }^{2}$ This semblance is too short to describe Tola and the importance that, as a mathematician and educator, he had in Peru. He was also a member of the Peruvian Academy of Language. See https://en.wikipedia.org/wiki/Jose_Tola_Pasquel
} 
https://es.wikipedia.org/wiki/Francisco_Miro_Quesada_Cantuarias, can be found an outline of his brilliant career. Reading [7] one concludes that with Miró Quesada, in 2019, passed away the last scholar to have had face-to-face mathematical contact with Alfred Rosenblatt, a reference for the modernization of University Mathematics in Peru. See footnote 5.

In the video-recorded interview at http://videos.pucp.edu.pe/videos/ver/c6e3554a206d4c938e9961e6635518e2, Tola recounts interesting aspects of the evolution of University Mathematics in Peru, touching in the fundamental role played by Alfred Rosenblatt in the thirties and forties.

I regard 1961 as the year of my Mathematical awareness in San Marcos. I am grateful to my Peruvian teachers for putting me in contact with good, universal, books. No one as Tola referred to them with so much deference, authority and erudition.

Toward the end of 1960 the career of Physics and Mathematical Sciences had trifurcated in Programs: Physics, Pure Mathematics, and Applied Mathematics. The Institute was removed from the structure of the Faculty of Sciences and the annual system had been transformed into the semester system, based on credits and prerequisites. The strange thing is that this "modernizing" revolution happened during the absence of Tola, Director of the Institute. Upon returning from his trip, he learned of the transformation when receiving his check payment and realizing that his gratification as Director was missing.

Several classmates from the 1959 group followed Applied Mathematics, and were oriented towards Statistics and, later, obtained the Magister in the CIENES (The Inter-American Statistical Training Center), Santiago de Chile.

After two years in Physics and Mathematics, in association with School of Education, by completing courses on Pedagogy and the Humanities, candidates could graduate as Bachelors of Education or Secondary School Teachers, after sustaining a Pedagogical Thesis.

Most of members of the 1959 Mathematics and Physics class, with the inspiration and devotion of those who embrace the teaching profession, a career that in Peru is still a synonym of an apostolate, followed this orientation. 
A few of them obtained a Doctorate in Education, becoming later Mathematics teachers at Universities and other undergraduate schools.

In 1987, twenty-five years after graduating in 1962, in a demonstration of selfaffirmation, organized in a sort of guild, and placed a commemorative plaque to a wall in the Science Courtyard of La Casona. There were listed the names of the twenty-four of the group that, in 1962, had graduated in Physics or Mathematics, Pure or Applied, by credits counting.

Already distant and alien, I saw later that my transition through the San Marcos classrooms had been engraved in bronze ${ }^{3}$.

If my records are correct, three of the fifty four students of the first year, reached later the PhD level, with publications, in Physics or Mathematics. The most distinguished and bold of the 1959 classmates was Jorge H. Moromisato, 1941 - 2018. He obtained a Doctorate as Physicist in Elementary Particles at Northeastern University, Boston, where he continued his scientific work at various Research Accelerators in USA and Europe. In 2006, after his retirement, he devoted himself to Political Economics, on which he published several books proposing his innovative views on this field.

With the elimination of the Institute in 1960, a valuable opportunity to develop Mathematical Research in San Marcos was missed, causing a historical delay. Now, with renewed faculty members, it has regained terrain ${ }^{4}$.

\section{The Brazilian Scholarship}

During my first three years in San Marcos, I acquired a working discipline and a technical-bookish knowledge that impressed my fellow students and some teachers.

Tola instigated by Ramos, decided that he should send me to another mathematical center, more advanced and active, even before the end of four standard years.

\footnotetext{
${ }^{3}$ However, this record on a wall of the elegant and centenarian La Casona was ephemeral. The plaque was removed for a remodeling of the walls and not replaced, alleging its loss. In 2009 a replication of it was placed on a wall of the new building of the Faculty of Mathematics, in the new University Campus, modern but without the ancestry and charm of La Casona.

${ }^{4}$ In the 1990s, thirty years after the impolite dismissal, the Faculty of Mathematics of San Marcos -a continuation of the Institute, with renewed faculty members- appointed Tola as Honorary Professor.
} 
"The fourth year is a waste of time; the only reasonable course, General Topology, occurs in the second semester," argued Ramos. He was right, the supply capacity had been exhausted. And the demand too. Already along the third year, with the exception of two or three students, the rest of the group no longer followed the "pure" mathematics courses.

Prof. Tola, convinced of the uselessness that for my mathematical progress would represent continuing at that moment in the meager fourth year of the University, he set out in search of a center of excellence where I could get a scholarship to continue my studies.

He wrote a letter to Prof. Alberto González Domínguez, from the University of Buenos Aires, recommending me for a fellowship from the Organization of American States (OAS) to spend a year at the Mathematics Institute in Buenos Aires.

"We have here a young fellow with a promising potential, we believe he should have the opportunity to pursue his studies in a center more advanced and active than ours." The answer never arrived.

In a second attempt, he wrote to Prof. Leopoldo Nachbin, inquiring about the possibility of obtaining a scholarship at the Institute of Pure and Applied Mathematics (IMPA), in Rio de Janeiro. The answer arrived promptly.

Nachbin was going to spend a long period outside Brazil. Nevertheless, Mauricio Peixoto, one of the bright pillars of the nascent Brazilian Mathematics, in a stop of his trip to the United States, was soon going to spend a night in Lima.

Thus, one night in November 1961, at the Crillón Hotel in Lima, Tola and Peixoto dined together and decided my mathematical future for 1962.

Tola started the conversation by recounting the setback that for Peruvian Mathematics had meant the elimination of the Mathematics Institute in San Marcos. Then, he talked about my case and the convenience that I continue my studies in a center of excellence. Peixoto was receptive.

"Maybe your young fellow could be integrated into the working group on the Qualitative Theory of Differential Equations that I will start next year at IMPA. However, I am worried by the fact that he will not yet be graduated", he said.

Then they discussed various issues. Tola talked about his mentor Alfred Rosen- 
blatt $^{5}$ (Krakow 1880 - Lima 1947), the first great professional mathematician to reach San Marcos, where he left a remarkable influence, establishing there contemporary subjects in teaching and research. See the works [5, 6], in Polish and [7] for an English version.

Peixoto recounted how he had discovered the reef of Structural Stability in the works of the Russian mathematicians Andronov and Pontrjagin and how, subsequently, he had met the great mathematician Solomon Lefschetz, who had also played a role in Peixoto's interest in his field of research. See the essay [23] for an elaborations of the author on this subject.

In the farewell after the meal, Peixoto said: "I will recommend your student to the Director of IMPA for a scholarship." He fulfilled the promise.

Days later, Tola communicated me that my best option was to go to Rio de Janeiro, to study Differential Equations at IMPA with the supervision of Prof. Peixoto.

"It is a very important area; furthermore the Brazilian Professor is a great expert in that field. He has made outstanding contributions, which will soon see the light, and about them we will hear for many years. We have to take this opportunity to update our mathematical scenario and develop it in our environment." He said in his charming stern style.

I had to write to the RIAS (Research Institute for Advanced Study), in Baltimore, introducing me to Peixoto, giving him an idea of the mathematical level that I had reached. I promptly did so. See the essay [21].

A few weeks later I received a letter from Dr. Lélio Gama, Director of IMPA, offering me a scholarship of Cr $\$ 30,000$ monthly for a one-year stay at IMPA (at my arrival in Rio de Janeiro, the "cafezinho", served in the corner bars, was priced Cr\$ $3.00)$.

Peixoto's response, short and objective, also arrived. Following his advice, during the summer of 1962, I read with enthusiasm the following books: Hurewicz, Differential Equations [10], complemented by parts of the more extensive and arduous Coddington-Levinson [8]. Also, I progressed considerably with Pontrjagin,

${ }^{5}$ https://es.wikipedia.org/wiki/Alfred_Rosenblatt 
Combinatorial Topology, [16], combined with parts of the classic Seifert-Threlfall, Topology Lessons, [17]. See [21].

I followed assiduously the recommendations of Peixoto, as an strenuous summer challenge. The reading prepared me for not be totally lost in the presentations of the seminar he had planned to run at IMPA, starting April 1962.

With a letter of recommendation from Dr. Lélio Gama, I got a place in the flight Lima-Rio of the Brazilian Air Force (FAB).

Endowed with a solid faith in books and the naive belief that by choosing them with good judgment I could fill in the gaps (or abysses) that separated me from higher knowledge and of research, I arrived in Rio de Janeiro on March 28, 1962.

\section{An interview with Prof. Peixoto}

Upon my arrival to IMPA, I went immediately looking for Peixoto to, naively, ask him for a program - a sort of syllabus - for my studies.

— Did you study all the book of Hurewicz? He interrogated me.

- The final chapter, about singular points, I did superficially. I replied.

- It is one of the most important parts. He said, and shifted off the subject.

- You must try to graduate to have a diploma. Do you understand? He said emphatically.

Would he be implying that I was short of understanding? At that time, not aware of the subtle differences between Portuguese and Spanish, I translated everything literally. In general, this works correctly, but that it hides some dangers.

About my request for a syllabus he did not say a word.

-- Do not get out of sight. He said, putting and end to the conversation.

I would have preferred, however, something like "Read this and that book" as, perhaps, some of my bibliophile San Marcos professors would have suggested to me; or even, "You must write in a pocket notebook the main results on Structural Stability, proved and illustrated in color," as my Plane Geometry high school teacher 
would have persuaded me to do. This last distant remembrance has been narrated in [18].

\section{Some activities at IMPA and back to Lima [20]}

I attended all the seminars and courses of IMPA, which were not too many. The courses were very rewarding and inspiring, I followed them with a critical mind, without the pressure of exams.

By far, the most advanced of all activities was the Seminar of Peixoto on the Qualitative Theory of Differential Equations. It was a challenge that surpassed me, from start to end, I strived to follow it with attention and determination.

Meanwhile, I had understood Peixoto's message regarding the importance of having a diploma. With the help of my classmate and best friend Delfina Ugás, I enrolled by correspondence in the fourth year of the San Marcos program. They would allow me to take the final exams, freeing myself from the presence in classes.

Thanks to the generosity of the FAB, which donated me two passages of RioLima-Rio at the request of Dr. Lélio Gama, "in favor of the relations of cooperation and mathematical exchange in Latin America," I was able to be present in San Marcos to take the exams of July and December.

Thus, at the end of 1962, I also managed to graduate in San Marcos. Later, after a bureaucratic procedure, I obtained a real light cardboard diploma of Bachelor in Mathematical Sciences.

I returned to Rio de Janeiro at the end of March 1963, with the IMPA scholarship renewed and the determination (stimulated by Peixoto) to work for a Doctorate. In my suitcase, I carried a first study of the note of Andronov and Leontovich on First Order Structural Stability [3], which later would be one of the fundamental elements of motivation for my Doctoral Thesis. Another, crucial, piece of motivation would come from the works of Peixoto [12], [13], [15].

The aforementioned note [3] consisted only of four pages, without any demonstration. Peixoto had handed it to me shortly before my trip to Lima, in November 1962, with the following recommendation: "Do not lose this paper. It is important."

My sojourn at IMPA, between 1962 and 1964, corresponded to a second initiation 
and mathematical awarenes - pertinent to research - definitive for me, superior in intensity to the first one, that of basic learning in San Marcos, from 1959 to 1961.

Along with that permanence I understood that the passage from bookish mathematics to living mathematics does not fit into pre-established patterns. It happens, I think now, when those interested in learning, observe the activity of those who produce and wish to teach it, and study their inspiring works. In the evocative essay [20], I recounted the experience of my stay in Brazil, 1962-64.

When we said goodbye in Rio de Janeiro, after my IMPA sojourn, Peixoto wrote two letters. One of them was for Tola, returning the shuttlecock he had received from him at the Crillón Hotel dinner in November 1961. With great elegance, he informed him that he had done his part of the deal and requested his help to get a Mathematics teaching appointment for me. The other letter was addressed to Prof. Stephen Smale, recommending me for an initial teaching position in the USA.

Without having premeditated it, towards the end of 1964, I impacted my Peruvian mentors with the problem of finding a job for a young doctor, without teaching experience. The ambient that, as was meager in the offer of advanced mathematics courses, was also so in the offering of full-time positions. No public competitions for University jobs existed at that time.

With irreproachable coherence, Tola, already distant from the command in San Marcos, asserted his prestige at the National University of Engineering, the Peruvian École Polytechnique, to get me an invitation to teach there.

Toward the middle of 1965, I received an invitation from the University of California for a position of Instructor of Mathematics, with documentation to apply for a working visa in USA.

\section{Epilogue}

I was very fortunate when, in 1959, destiny led me to the only place in Peru where one could learn the basics of Real and Complex Mathematical Analysis, Modern Algebra and Differential Geometry. There I could encounter Prof. José Tola, the first of the wise men in the world of Mathematics with whom I had contact throughout long years of activity. Through him I could still sense some reverberations of the 
influence of Alfred Rosenblatt in San Marcos. In the essay [21] I tell about other encounters with remarkable mathematicians, among them Peixoto and Smale, already mentioned, and also René Thom.

With a strike of luck, the hand of fate put Tola in contact with Peixoto in November 1961. On that month he had submitted for publication his master work on Structural Stability [15], and had already decided to organize mathematical activities at IMPA to stimulate people to pursue advanced studies leading to research on the Qualitative Theory of Differential Equations, and was receptive to newcomers. On July 1961 he had delivered a plenary lecture on Structural Stability at the Third Brazilian Mathematics Colloquium held in Fortaleza, Ceará [14]. Three of the attendants to his inspiring lecture converged in 1962 at his seminar in IMPA and worked under his supervision [20].

At the emblematic Crillón Hotel ${ }^{6}$, in Lima, with a toast of a foaming Pisco Sour tasty drink, Peixoto and Tola sealed what came to be my mathematical future.

\section{Acknowledgements}

This article originated on a free translation of the essay [19], which was revised, corrected and considerably upgraded in the present version. The author is grateful to Maria Michalska for her help in translating parts of [5] and [6], to Celinda P. Moromisato for her pertinent style suggestions, and to Luis F. Mello and Ronaldo

A. Garcia for their manifold aid.

The author is a fellow of CNPq, Process: PQ-SR-307690/2016-4.

\section{References}

[1] ALFHORS, L. Complex Analysis. New York: McGraw-Hill, 1953.

[2] Ampuero AguAYO, J. V. Aritmética Teórica. Lima: Universidad Nacional Mayor de San Marcos, 1960. (Patronato del Libro Universitario).

[3] ANDRONOV, A. A.; LEONTOVICH, E. Sur la theorie de la variation de la structure qualitative de la division du plan en trajectoires, Dokl. Akad. Nauk., v. 21, p. 427-430, 1938.

\footnotetext{
${ }^{6}$ Closed as a Hotel in 1999. Presently the building hosts numerous business offices.
} 
[4] APOSTOL,T. M. Análisis Matemático. Segunda Ed. Barcelona: Reverté, 1976.

[5] CIESIELSKA, D.; MALIGRANDA, L. Alfred Rosenblatt (1880 - 1947). Wiad. Mat., v. 50, n. 2, p. 221-259, 2014. (Polskie Towarzystwo Matematyczne, Polish)

[6] CIESIELSKA, D.; MALIGRANDA, L. Alfred Rosenblatt (1880 - 1947). Antiquitates Mathematicae, v. 8, n. 1, p. 3-45, 2014. (Publications, Courses and Lectures - Polish with English Abstract)

[7] CIESIELSKA, D.; MALIGRANDA, L. Alfred Rosenblatt (1880 - 1947): Polishperuvian mathematician. Function Spaces XII, Banach Center Publications, v. 119, p. 57-108, 2019.

[8] CODDIngton, E.; LEVInSON, N. Theory of Ordinary Differential Equations. New York: McGraw Hill, 1955.

[9] DICKSON,L. E. New First Course in the Theory of Equations. The Project Gutenberg E-Book. Available at: http://www.gutenberg.org/files/29785/29785-pdf. Acessed: Nov. 12, 2020.

[10] HUREWICZ, W. Lectures on Ordinary Differential Equations. New York: J. Wiley and Sons, 1958.

[11] MIRÓ QUESADA CANTUARIAS, F. Filosofía de las Matemáticas. Curso en la Escuela del Instituto de Ciencias Físicas y Matemáticas de la facultad de Ciencias de San Marcos, Mimeo. 2 Vol. Lima, circa 1955. Reprinted by Ignacio Prado Pastor, Editor, Lima, 1980.

[12] PEIXOTO, M. M. On structural stability. Ann. Math., v. 69, p. 199-222, 1959.

[13] PEIXOTO, M. M.; PEIXOTO, M. C. Structural stability in the plane with enlarged boundary conditions. Anais da Academia Brasileira de Ciências, v. 31, p. 135-160, 1959.

[14] PEIXOTO, M. M. Sobre o problema fundamental da teoria qualitativa das equações diferencias. In: COLÓQUIO BRASILEIRO DE MATEMÁTICA, n. 
3, 1961, Fortaleza. Atas do terceiro Colóquio Brasileiro de Matemática. Rio de Janeiro: IMPA, p. 190-194, 1961.

[15] PEIXOTO, M. M. Structural stability on two-dimensional manifolds. Topology, v. 1, p. 101-120, 1962.

[16] PONTRYAGIN, L. S. Foundations of Combinatorial Topology. New York: Dover Publications, 2015.

[17] SEIFERT,H.; THRELFALL, W. Lecciones de Topología. Madrid: Instituto Jorge Juan de Matemáticas, 1951. (Colección de Textos de Matematica Moderna I)

[18] SOTOMAYOR, J. A caderneta de geometria. Revista do Professor de Matemática, v. 21, p.1-5, 1992.

[19] SOTOMAYOR, J. Las matemáticas superiores: reminiscencias de aprendizaje. Pro-Mathematica, v. 8, p. 15-16, 1994.

[20] SOTOMAYOR, J. Uma lista de problemas de EDO. Revista de Matemática e Estatística-UNESP, v. 18, p. 223-245, 2000.

[21] SOTOMAYOR, J. Mathematical encounters. ICCM Not., v. 6, n. 2, p. 94-98, 2018.

[22] SOTOMAYOR, J. On a list of ordinary differential equations problems. São Paulo J. Math. Sci., v. 13, n. 1, p. 177 - 194, 2019.

[23] SOTOMAYOR, J. On Mauricio M. Peixoto and the arrival of Structural Stability to Rio de Janeiro, 1955. An. Acad. Bras. Ciênc. v.92, n.1, 2020.

[24] VAN DER WAERDEN, B. Modern Algebra. New York: Frederick Ungar Publishing Co., 1949.

[25] WILlmorE, T. J. Differential Geometry, Glasgow, New York: Oxford Univ. Press, 1959.

Submetido em 1 Jun. 2020

Aceito em 18 Jun. 2020

NEXUS Mathematicæ, Goiânia, v. 3, 2020, e20007. 